\title{
29. EOCENE TO EARLY MIOCENE BENTHIC FORAMINIFERA' DSDP LEG 39, SOUTH ATLANTIC
}

\author{
Anne Boersma, Lamont-Doherty Geological Observatory, Palisades, New York
}

\section{INTRODUCTION}

Few reports of benthic foraminiferal faunas from deep-sea cores of the Tertiary have been published. Notable exceptions are the works of Berggren (1972, 1975), Douglas (1973), and Vincent et al. (1974) on samples taken by the Deep Sea Drilling Project. Older works, providing the reference faunas for these deeper, open marine sections include Beckmann (1953), Bandy (1970), Cushman and Renz (1948), Cushman and Stainforth (1945), Palmer (1940), AGIP (1959), and Bermudez (1949): see Berggren and Phillips (1971) for a more extensive bibliography. Because of the time between publication of these two groups of works, and although some taxonomic revisions are presently in progress (for example, Tjalsma, personal communication), there is currently a lack of standardized and updated taxonomy. Consequently, the faunas reported here are given names directly from the older literature and the source of each name is listed in the Appendix. When the taxonomy is revised it will then be reasonably simple to incorporate the taxa listed in this report.

Benthic foraminifera were studied from the Tertiary of Sites 356, 357, 358, and 359 (Table 1), and those-both the smaller and larger forms-from Site 357 are treated in greater detail. Coring gaps, hiatuses, and preservational effects resulted in less complete sections at the other sites.

Presently, one of the crucial problems in the study of benthic foraminifera, particularly those of the geologic past, is to reinterpret their distribution patterns in terms of chemical, physical, and/or biological parameters. The seemingly straightforward explanation of water depth as a controlling factor has been questioned in recent years (Streeter, 1973; Douglas, 1973). Thus, one of the purposes of this study is to document faunal changes at this site with accompanying temperature fluctuations determined from oxygen isotope ratios.

Stratigraphic and evolutionary conclusions from this sort of study are few, as appearances and disappearances at the site may be ecological rather than evolutionary events.

\section{SITE 357}

Site 357 lies approximately $30^{\circ} \mathrm{S}, 30^{\circ} \mathrm{W}$ at a present water depth of 2086 meters. The site is within the

\footnotetext{
'The author has expressed strong preference for using "foraminifera" rather than the common form "foraminifer." Although the DSDP editors feel that the common form of the word is preferable in English, and for consistency have decided to use it in the Initial Reports, they accede here to the author's wishes.
}

present depth range of the North Atlantic Deep Water on the eastern flank of the Rio Grande Rise (Figure 1).

Reconstruction of South Atlantic plate motions and spreading (Ladd, 1974) indicates that in the early Tertiary the site lay farther south and moved gradually northward as the Tertiary progressed. It is now in the subtropical zone, but may have been within the warmer subtropical zone during the warmer periods of the early Tertiary.

The stratigraphic distrubutions of key benthic species from the Eocene into the Miocene are shown in Figure 2. Most discontinuities in the stratigraphic ranges result from the fact that an aliquot, not the entire sample, was picked for benthic foraminifera.

The faunas of Site 357 are very similar to those reported from the Pacific by Douglas (1973). The most obvious differences are (1) the Pacific samples lack lagenids, which are present and are occasionally abundant at Site 357; and (2) the greater significance of pleurostomellids at Site 357. The faunas examined in this study are otherwise remarkably similar in content and diversity in both areas from Eocene into early Miocene time.

\section{Larger Benthic Foraminifera}

A shallow water fauna of larger benthic foraminifera accompanied a volcanic sequence of rocks and sediments in Core 25. This displaced fauna, along with the volcanic material, undoubtedly moved downslope from a topographic high adjacent to the site. These larger foraminifera are shown in Plate 1.

Significant among the typically middle Eocene fauna was the presence of operculinid nummulites. Nummulites are rare outside the eastern Tethys (including the Mediterranean); in fact, only two groups are known to have colonized the Caribbean (Blondeau, 1968). Because of the latitude of the Rio Grande Rise in the early Tertiary, it could hardly have been a "stepping stone" for the trans-Atlantic migration of larger benthics. Therefore, it seems larger benthic foraminifera reached the Rio Grande Rise via the South American shelf.

The total fauna is strongly reminiscent of the middle Eocene (Lutetian) larger foraminiferal faunas of Italy (AGIP, 1959). Although specific identifications have not yet been made, the genera present include: Linderina, Sphaerogypsina, Pseudophragmina, operculinid nummulites, Fabiania, Discocyclina, and lepidocyclinids, as well as rotalids, bryozoa, and calcareous algae.

Planktonic foraminifera were mixed in with the larger benthic foraminifera. They were apparently contemporaneous with the sediment containing the volcanic rocks and other invertebrate fossils. No other larger foraminifera were found. 


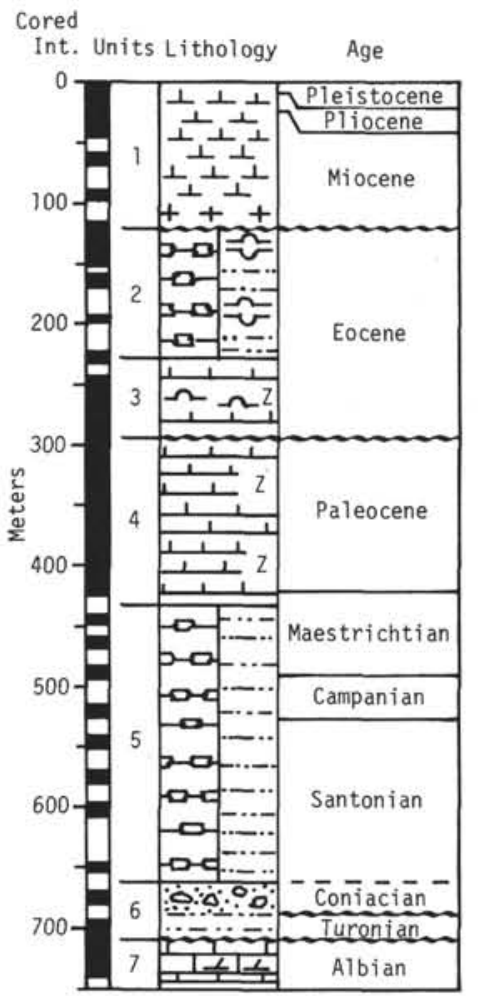

359

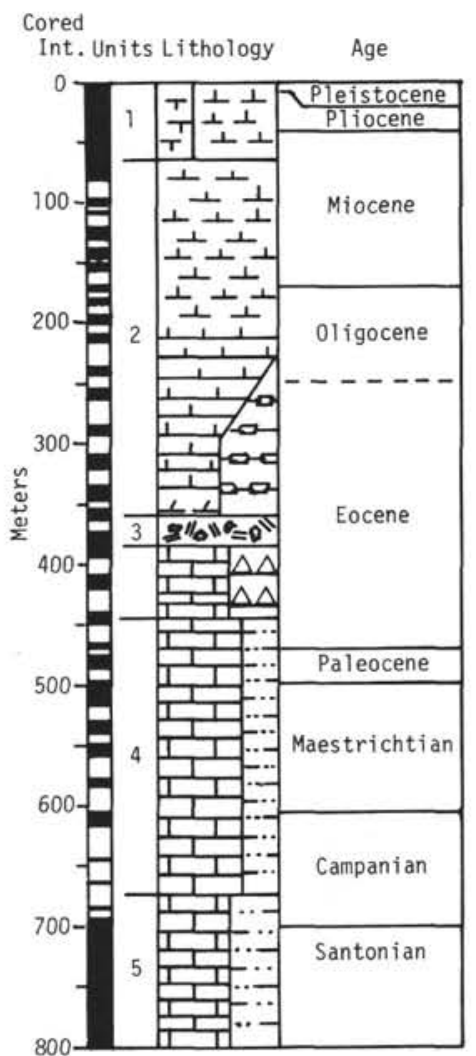

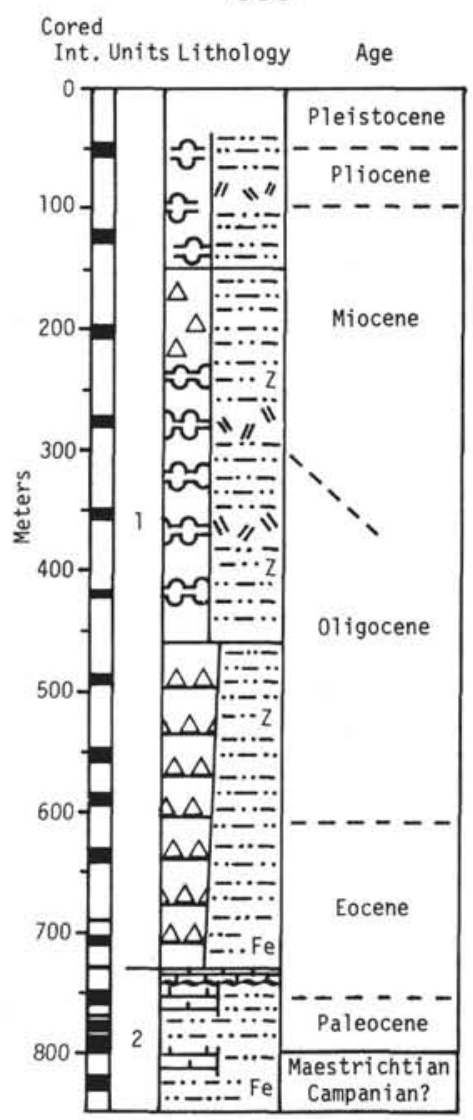

Cored

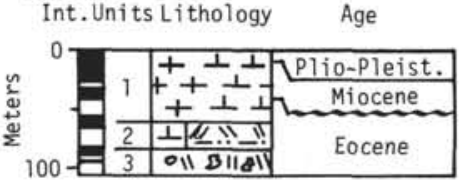

Figure 1. Location maps and biostratigraphic column drilled during Leg 39. (Reconstructions from McCoy and Zimmerman, this volume.)

TABLE 1

Data on Sites Studied for Benthic Foraminifera, Leg 2

\begin{tabular}{|c|c|c|c|c|c|c|}
\hline Site & $\begin{array}{l}\text { Present } \\
\text { Latitude }\end{array}$ & $\begin{array}{c}\text { Present } \\
\text { Longitude }\end{array}$ & $\begin{array}{c}\text { Present } \\
\text { Water } \\
\text { Depth } \\
(\mathrm{m})\end{array}$ & $\begin{array}{l}\text { Age of Oldest } \\
\text { Recovered } \\
\text { Sediments }\end{array}$ & $\begin{array}{c}\text { Cored } \\
\text { (m) }\end{array}$ & $\begin{array}{c}\text { Recovery } \\
\text { (\%) }\end{array}$ \\
\hline 356 & $28^{\circ} 17^{\prime} \mathrm{S}$ & $41^{\circ} 05^{\prime} \mathrm{W}$ & 3175 & $\begin{array}{l}\text { Late } \\
\text { Albian }\end{array}$ & 333 & 76 \\
\hline 357 & $30^{\circ} 00^{\prime} \mathrm{S}$ & $35^{\circ} 33^{\prime} \mathrm{W}$ & 2086 & Santonian & 209 & 73 \\
\hline 358 & $37^{\circ} 39^{\prime} \mathrm{S}$ & $35^{\circ} 57^{\prime} \mathrm{W}$ & 4962 & $\begin{array}{l}\text { Late } \\
\text { Campanian }\end{array}$ & 28 & 59 \\
\hline 359 & $34^{\circ} 59^{\prime} \mathrm{S}$ & $4^{\circ} 29^{\prime} \mathrm{W}$ & 1655 & $\begin{array}{l}\text { Late } \\
\text { Eocene }\end{array}$ & 27 & 55 \\
\hline
\end{tabular}

\section{Stratigraphic Distributions of Key Species}

Based on the ranges of species at Site 357, a table of age-restricted species in the South Atlantic has been assembled (Table 2). At Site 357 the number of species restricted to a given epoch approximates the number of species restricted to the key time periods of Douglas (1973). It is perhaps too early to interpret the evolutionary changes in Tertiary benthic foraminifera without careful group-by-group studies and taxonomic revisions.

\section{SITE 356}

Benthic foraminifera are generally rare in most samples at Site 356. Levels subjected to slight 

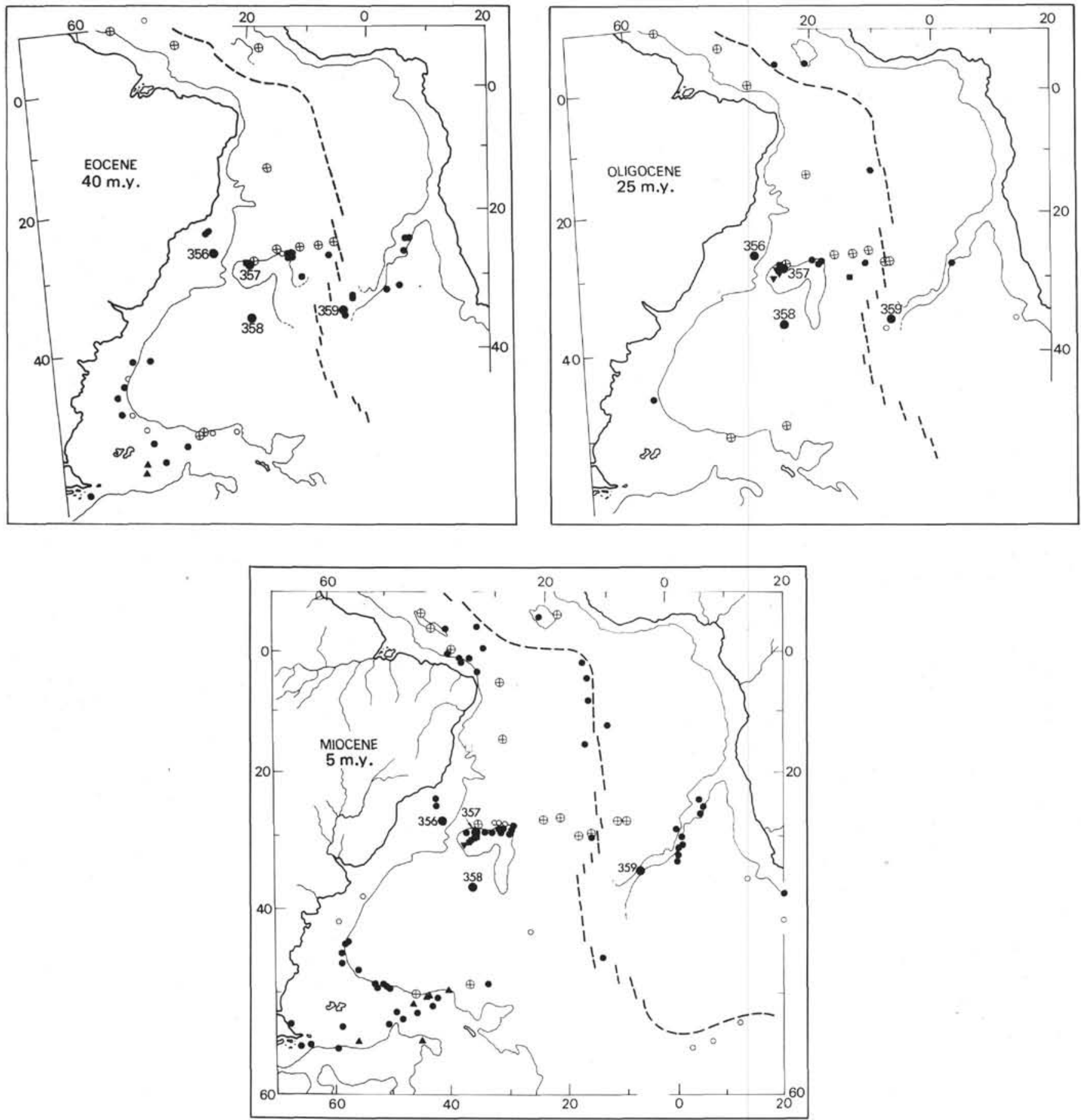

Figure 1. (Continued).

dissolution, not surprisingly, have larger benthic foraminiferal faunas. The Eocene sediments at Site 356, however, contain levels with exceptional degrees of dissolution and diagenetic alteration which also destroyed the benthic foraminifera. Faunas from selected intervals are shown in Figure 3.

Many species occurring at Site 356 are also found at Site 357. Site 356, however, must have lain in water depths between 2000-3000 meters and apparently was deeper than Site 357 throughout the Tertiary. Several features of the Site 356 faunas distinguish them from those of Site 357:

1) Persistent greater abundance of spinose rectilinear forms and abundance of rectilinear forms;

2) Greater abundance of Nuttallides truempyi;

3) Lack of the large specimens typical of some Site 357 residues deposited during cooling episodes;

4) Presence of Pulvinulinella, even in highly dissolved faunas;

5) Lack of Uvigerina species except $U$. cf. auberiana; 


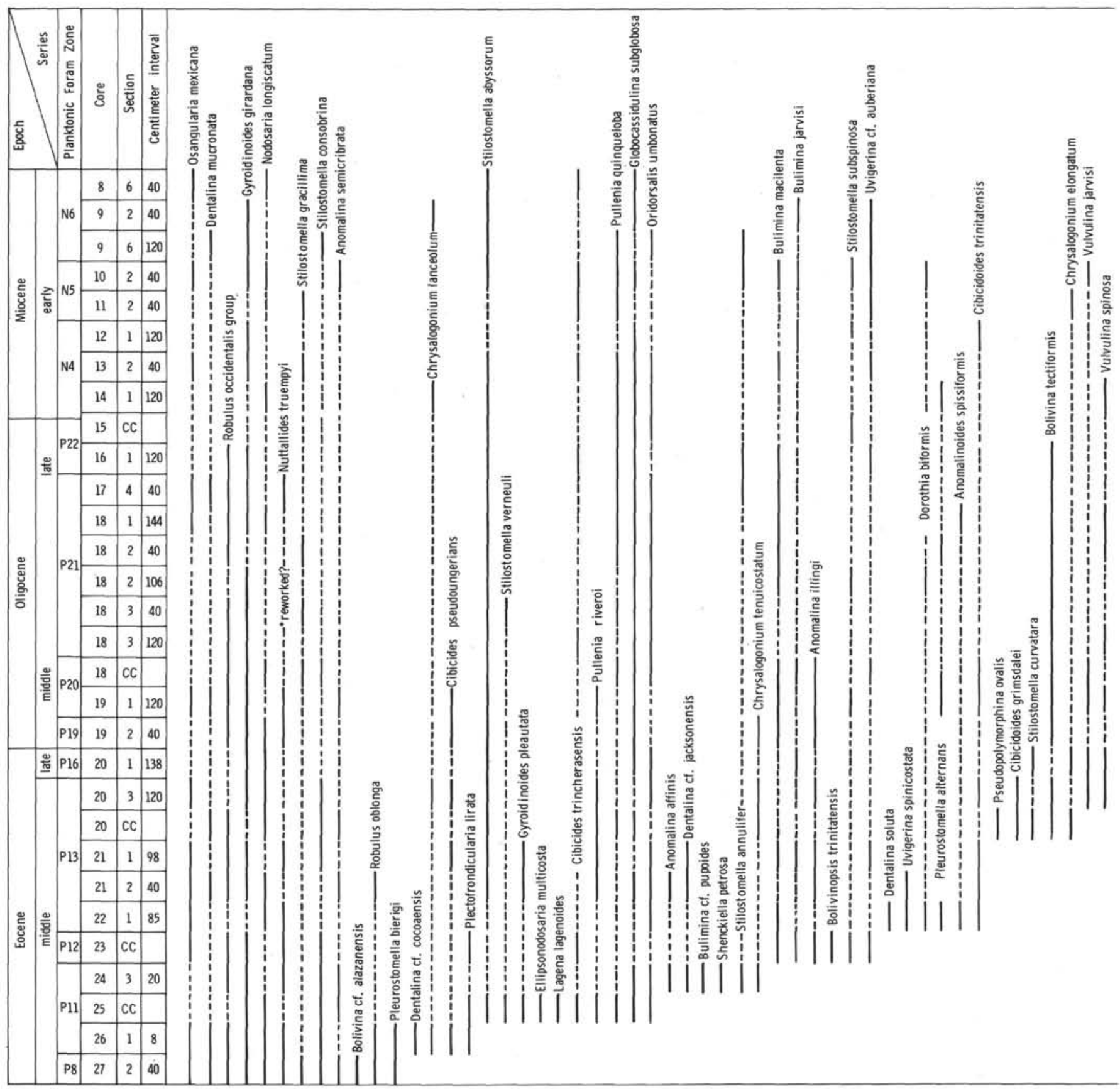

Figure 2. Stratigraphic ranges (Eocene-lower Miocene) of selected benthic foraminifera of DSDP Leg 39, Site 357.

6) Low abundances of Cibicides spp., anomalinids, and bolivinids.

\section{Faunas}

Faunas at Site 356 in the early Eocene are dominated by a Pleurostomella-Nuttallides fauna which, according to Bandy (1970), characterizes the abyssal zone during the early Paleogene.

Later, faunas at Site 356 evolve from a Pleurostomella-Nuttallides fauna to ones dominated by Pleurostomella-Stilostomella including $S$. gracillima, $S$. consobrina, $S$. abyssorum, and $S$. aculeata; planktonic foraminifera are rare. This type of fauna containing few benthics, primarily the rectilinear species and dominated by Stilostomella, is typical in certain levels of the Oceanic Formation of Barbados which contain radiolarians, few benthics and few or no planktonic foraminifera.

The lack of planktonic foraminifera is probably the result of dissolution in the Oceanic Formation as well as at Site 356. At Site 356 the majority of in situ benthic foraminifera were also lost from the sediments deposited in water depths of only from 2000 to 2500 meters during the latter part of the Eocene.

One interval with an influx of species more typical of Site 357, including the Robulus occidentalis group and Bulimina jarvisi, occurs in Core 10 , section 2 to sample 9 , CC. The interval is characterized by improved 


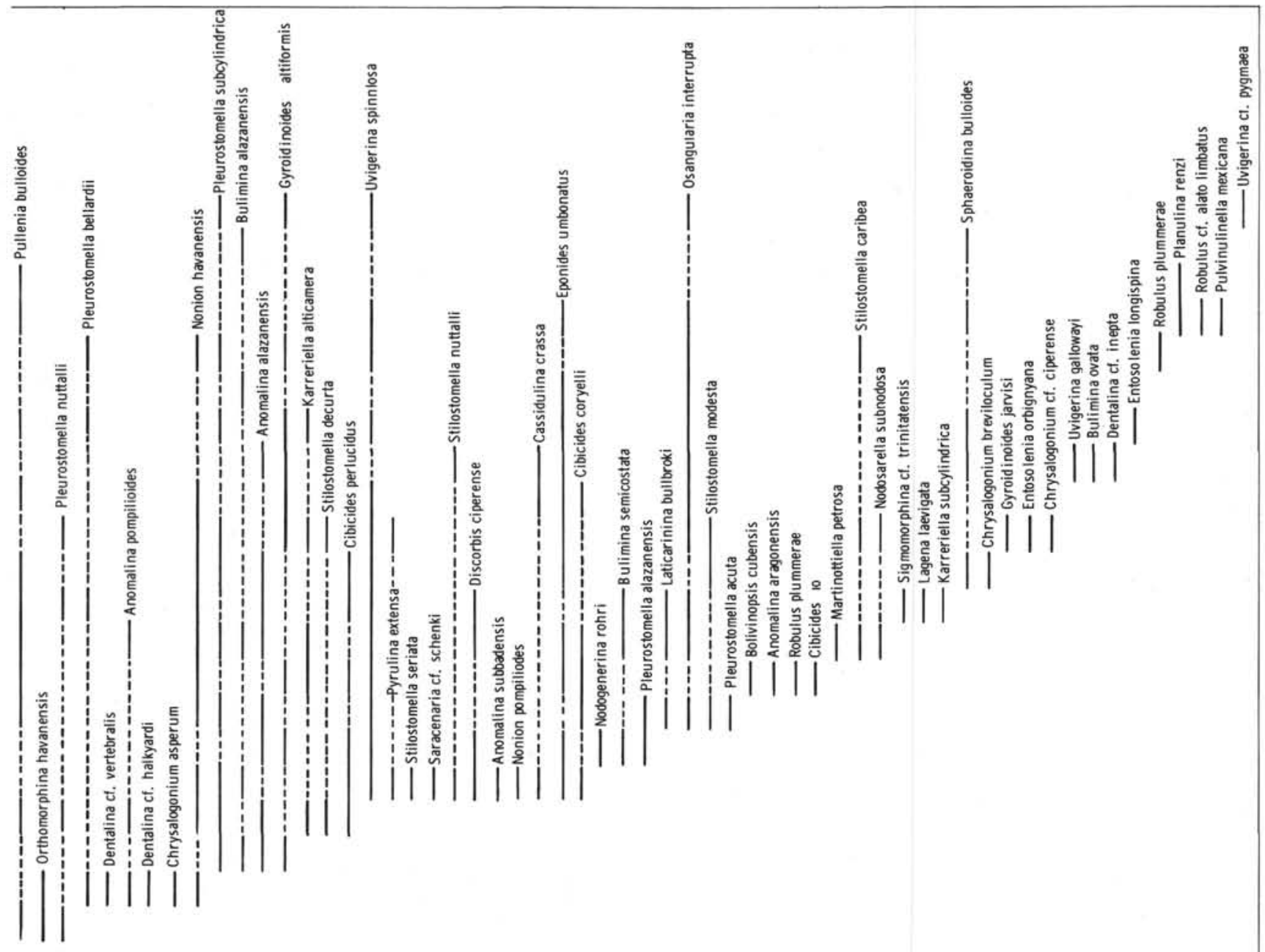

Figure 2. (Continued).

preservation up section beginning in Core 10, and an influx of radiolarians and diatoms. It corresponds to planktonic forminiferal Zone P8 of the middle Eocene. These forms may be displaced or are a result of downslope migration of faunas. At this time at Site 357 there is a significant increase both in the near surface and bottom temperatures. Presumably a similar temperature change occurred at Site 356, and the warming could have resulted in downslope displacement of water masses, migration of the robulinids and buliminids, as well as the decreased ratio of spiny and rectilinear to rotaloid species.

Throughout the rest of the Eocene at Site 356, rectilinear and spinose forms dominate the faunas. In strongly dissolved samples only pieces of lagenids, pleurostomellids, and stilostomellids are found; Nuttallides truempyi is absent. Lagenids become increasingly more abundant higher in the section:

Early Miocene faunas in Cores 3 and 4 strongly resemble those of the Eocene. Spiny stilostomellids, pleurostomellids, and lagenids dominate these sparse faunas. These faunas probably lived in water depths of greater than 2500 meters but less than 3000 meters.

Pulvinulinella persists even in the most dissolved and recrystallized faunas at Site 356. According to Loeblich and Tappan (1964), Pulvinulinella is a junior synonym of Epistominella. Interestingly, the Recent species, $E$. exigua is characteristic of greatest depths (Streeter, 
TABLE 2

Species Restricted to an Epoch at Site 357

\begin{tabular}{lll}
\hline \multicolumn{1}{c}{ Eocene } & \multicolumn{1}{c}{ Oligocene } & \multicolumn{1}{c}{ Miocene } \\
\hline Robulus oblonga & Cibicides perlucidus & Plaunlina renzi \\
Gyroidina planulata & Pyrulina extensa & Robulus alatolimbatus \\
Anomalinoides affinis & Bulimina semicostata & \\
Nuttallides truempyi & Pleurostomella alazanensis & \\
& Laticarinina bullbroki & \\
& Anomalina aragonensis &
\end{tabular}

Species Restricted to Key Time Intervals at Site 357

\begin{tabular}{|c|c|c|}
\hline $\begin{array}{l}\text { Middle Eocene- } \\
\text { late Oligocene }\end{array}$ & $\begin{array}{l}\text { Late Oligocene- } \\
\text { early Miocene }\end{array}$ & $\begin{array}{l}\text { Eocene- } \\
\text { early Oligocene }\end{array}$ \\
\hline Anomalina spissiformis & Stilostomella caribbea & $\begin{array}{l}\text { Chrysalogonium } \\
\text { tenuicostatum }\end{array}$ \\
\hline Bolivina tectiformis & S. bulloides & \\
\hline $\begin{array}{l}\text { Pleurostomella nuttali } \\
\text { Anomalina pompiloides }\end{array}$ & Osangularia interrupta & \\
\hline
\end{tabular}

Long Ranging and Widely Distributed Species

Uvigerina cf. auberiana Pullenia bulloides

Globocassidulina subglobosa Pullenia quinqueloba

Oridorsalis umbonatus Stilostomella abyssorum

1976, personal communication) and is found in Recent faunas from piston cores taken in deep water of the circum-Antarctic region (unpublished data). This genus appears to have high dissolution resistance and to have occurred in cold deep waters both in the Eocene and the Recent.

\section{SITE 359}

There is disagreement over the water depth in the late Eocene (P16) at Site 359 (Fodor et al., this volume; Boersma, this volume). The foraminiferal fauna listed below, rich in Robulus and large nodosarids, contains both a shallower and a deeper component (Table 3). The deeper component resembles faunas at Site 357, although the charactistic cosmopolitan species Globocassidulina subglobosa, Nuttallides truempyi, Uvigerina spinicostata, and Pullenia bulloides are not present. Apparently the deeper fauna is in place and the shallow water species were displaced downslope along with the volcanic materials.

\section{PALEOTEMPERATURE AND BENTHONIC FORAMINIFERAL RESPONSE}

Several indices were used to characterize benthonic faunas during times of temperature change:

Benthic Number $(\mathrm{BN})$ as a simple measure of the abundance of benthic foraminifera, and hence the planktonic benthic ratio, the benthic number was estimated from a sample of standard weight. In a preliminary analysis such as this, this simple index gives a first approximation of the abundance of the benthics, although a total picking of the sample would be more reliable in any detailed analysis of the faunas.

The ratio of rectilinear forms to rotaloid forms was estimated by Douglas (1973) and has been investigated here, as changes in this index appear to coincide with changes in the oxygen isotope record and thus with paleotemperature changes at the site.
TABLE 3

Benthic Species From Site 359, Core 3

\begin{tabular}{ll}
\hline \multicolumn{1}{c}{ Species also present at Site 357 } & \multicolumn{1}{c}{ "Shallower" Species } \\
\hline Bulimina macilenta & Saracenaria hantkeni \\
B. jarvisi & Ellipsoglandulina glabra \\
Stilostomella abyssorum & Nonion chapapotense \\
Vulvuina spinulosa (elongate form) & Marginulina spp. \\
Robulus occidentalis Group & Chrysalogonium longiscatum \\
Pleurostomella acuta & Planulina cocoaensis \\
Oridorsalis umbonatus & Anomalina granosa \\
Pullenia quinqueloba & Dentalina jacksonensis \\
Uvigerina havanensis & Marginulina cf. cocoaensis \\
Anomalina semicribrata & Nodosaria latejugata \\
Osangularia mexicana & + pelecypod fragments \\
Dentalina mucronata & bryogoan fragments \\
Cibicides pseudoungerians & hystrichospheres \\
& volcanic glass \\
& volcanic rock fragments \\
\hline
\end{tabular}

Spinosity is a marker of differing environments; it has been found that some genera respond to changing conditions by producing more spiney morphotypes. The degree of spinosity within a species as well as the number of spinose species does appear to change during times of temperature change. This is true of both the rectilinear hyaline and agglutinated foraminifera.

Diversity of benthic faunas changes irregularly, generally consistently with times of temperature change, but diversity in a standard sized sample is largely a function of the amount of planktonics accumulating at a site, as the greater planktonic abundance will affect both the BN and the diversity. However, as these values are not always parallel, there must be other factors affecting diversity at the site, particularly in closely spaces samples.

Generalists versus specialists. There are several deep marine species which may be called generalists and/or cosmopolitan. These species have long stratigraphic 


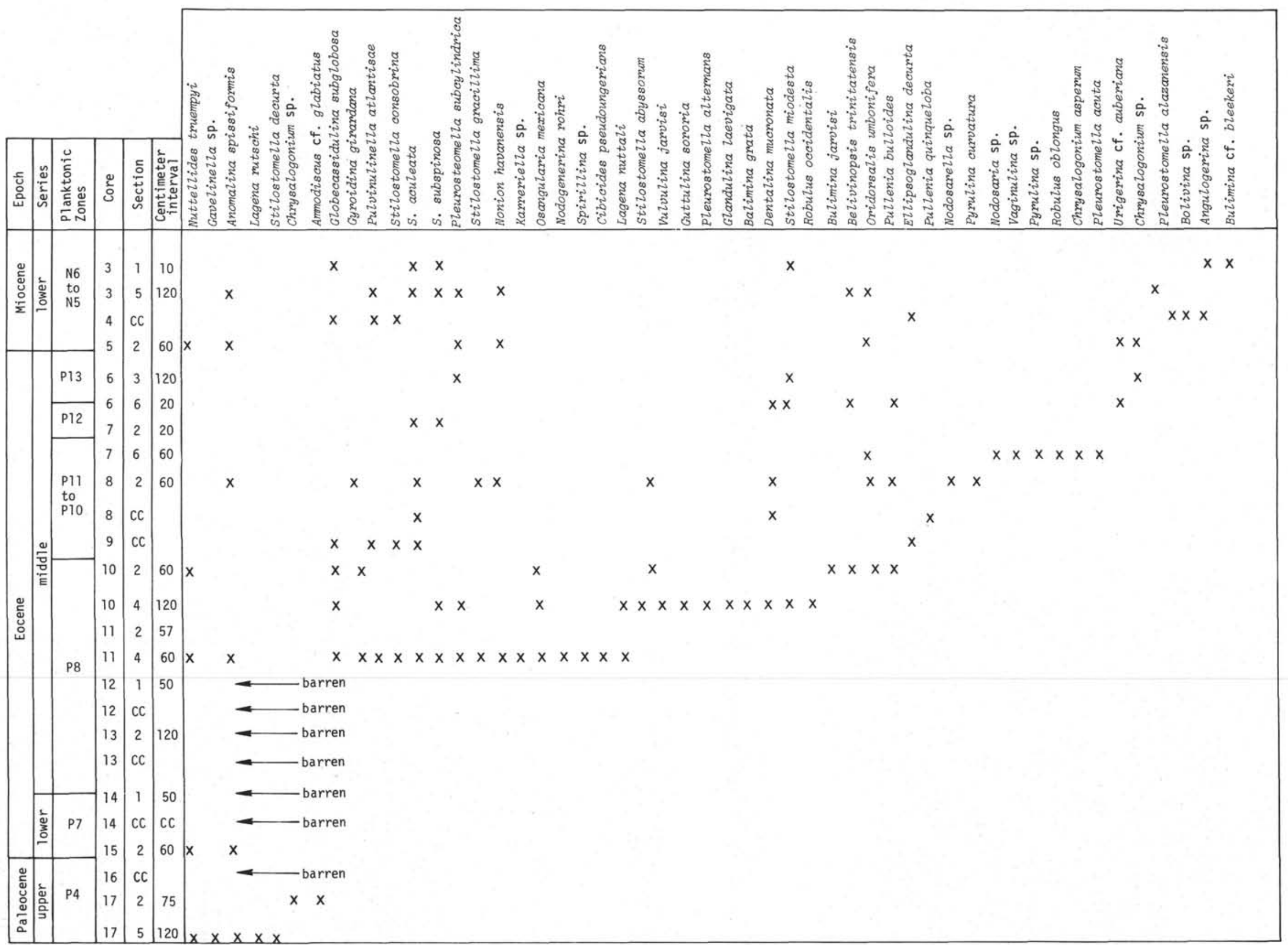


ranges, as well as wide vertical and geographic ranges. The number of these forms in populations appears to alter during times of temperature change, but these results are very preliminary.

The analysis of benthic foraminiferal response to paleotemperature changes at Site 357 are discussed in Boersma and Shackleton (this volume). The following conclusions can be reiterated:

1) that during times of significant change in the temperature signal, as recorded in the oxygen isotopes, there are interspecific as well as intraspecific responses in the benthic foraminifera. For example, at this depth during a cooling the benthic forams demonstrate increased spinosity, increased numbers of rectilinear species, increased numbers of benthic relative to planktonic foraminifera, increased number of generalists, or cosmopolitan species, and increased size of individuals;

2) that large individuals (for example, Cibicides perlucidus) were not necessarily redeposited, as the ${ }^{18} \mathrm{O}$ values may correspond to those of smaller species as well as to smaller individuals of the same species in a sample;

3) that the response of benthic faunas was not dependent upon sudden depth changes as the depth estimates from both ostracodes, and Cretaceous benthic foraminifera, are close to the present-day depth of the site.

\section{REFERENCES}

AGIP, 1959. Microfacies italiane; Milan (S. Donato).

Bandy, O.L., 1970. Upper Cretaceous-Cenozoic paleobathymetric cycles, Eastern Panama and Northern Columbia: Gulf Coast Assoc. Geol. Soci, v. 20, p.

Berggren, W.A. and Phillips, J.D., 1971. The influence of continental drift on the distribution of Cenozoic benthonic foraminifera in the Mediterranean and Caribbean-Gulf Coast regions. In Symposium Geol. Libya (Tripoli, 1969) Proc: Beirut, (Catholic Press), p. 263-299.

Bermudez, P. 1949. Tertiary smaller foraminifera of the Dominican Republic: Cushman Lab. Foram Res. Spec. Publ. 25.

Cushman, J.A. and Renz, H.H., 1946. The foraminiferal fauna of the Lizard Springs Formation of Trinidad, British West Indies: Cushman Lab. Foram. Res. Spec. Pub 18.

Cushman, J.A. and Renz, H.H., 1947. The foraminiferal fauna of the Oligocene, St. Croix Formation of Trinidad, B.W.I.: Cushman Lab. Foram. Res. Spec. Pub.22.

1948. Eocene foraminifera of the Navet and Hospital Hill Formations of Trinidad, B.W.I.: Cushman Lab Publ. Foram. Res. Spec. Pub 24, p. 1-42.

Cushman, J.A. and Stainforth, R.M., 1945. The formaninifera of the Cipero Marl Formation of Trinidad, British West Indies: Cushman Lab. Foram. Res. Spec. Publ. No 14, p. 3-75.

Douglas, R.G., 1973. Benthonic foraminiferal biostratigraphy in the Central North Pacific, Leg 17, Deep Sea Drilling Project. In Winterer, E.L., Ewing, J.I., et al., Initial Reports of the Deep Sea Drilling Project, Volume 17, Washington (U.S. Government Printing Office), p. 607-672.

Ladd, J.W., 1974. South Atlantic sea floor spreading and Caribbean tectonics: Ph.D. Thesis, Columbia University, N.Y.
Loeblich, A.R. and Tappan, H., 1964. Protista. SarcodinaChiefley Thecamoebians and Foraminiferida: Geol. Soc. Am. (Univ. of Kansas Press).

McKenzie, D. and Sclater, J.G., 1971. The evolution of the Indian Ocean since the late Cretaceous: Geophys. J. Ray Astron. Soc., 25, p. 431-528.

Palmer, D.K., 1940/1941. Foraminifera of the upper Oligocene Cojmar Formation of Cuba: Mem. Soc. Cub. Hist. Nat. 14.

Streeter, S.S., 1973. Bottom water and benthonic foraminifera in the North Atlantic/glacial-interglacial contrasts: Quat. Res., v. 3, p. 131-141.

Vincent, E., Gibson, J.M., and Brun, L., 1974. Paleocene and early Eocene microfacies, benthonic foraminifera, and paleobathymetry of Deep Sea Drilling Project Sites 236 and 237, western Indian Ocean. In Fisher, R.L., Bunce, E.T., et al., Initial Reports of the Deep Sea Drilling Project, Volume 24: Washington (U.S. Government Printing Office), p. 859-885.

\section{APPENDIX}

\begin{tabular}{|c|c|}
\hline Fossil Name & Reference \\
\hline Anomalina affinis & Cushman and Renz, 1948 \\
\hline Anomalina alazanesis & Beckmann, 1953 \\
\hline Anomalina aragonensis & Beckamnn, 1953 \\
\hline Anomalina illingi & Beckmann, 1953 \\
\hline Anomalina pompilioides & Beckmann, 1953 \\
\hline Anomalina semicribrata & Beckmann, 1953 \\
\hline Anomalina spissiformis & Beckmann, 1953 \\
\hline Anomalina subbadensis & Cushman and Stainforth, 1945 \\
\hline Bolivina cf. alazanensis & Cushman and Renz, 1948 \\
\hline Bolivina tectiformis & Beckmannm 1953 \\
\hline Bolivina tectiformis & Beckmann, 1953 \\
\hline Bolivinopsis cubensis & Beckmann, 1953 \\
\hline Bolivinopsis trinitatensis & Beckmann, 1953 \\
\hline Bulimina alazanensis & Cushmann and Renz, 1948 \\
\hline Bulimina jarvisi & Beckmann, 1953 \\
\hline Bulimina macilenta & Beckmann, 1953 \\
\hline Bulimina ovata & Beckmann, 1953 \\
\hline Bulimina cf. pupoides & Cushman and Renz, 1948 \\
\hline Bulimina semicostata & Cushman and Renz, 1948 \\
\hline Cassidulina crassa & Beckmann, 1953 \\
\hline Chrysalogonium asperum & Beckmann, 1953 \\
\hline Chrysalogonium breviloculum & Cushman and Stainforth, 1945 \\
\hline Chrysalogonium cf. ciperense & Cushman and Stainforth, 1945 \\
\hline Chrysalogonium elongatum & Beckmann, 1953 \\
\hline Chrysalogonium lanceolum & Beckmann, 1953 \\
\hline Chrysalogonium tenuicostatum & Beckman, 1953 \\
\hline Cibicides coryelli & Beckmann, 1953 \\
\hline Cibicides grimsdalei & Beckmann, 1953 \\
\hline Cibicides io & Cushman and Stainforth, 1945 \\
\hline Cibicides perlucidus & Beckmann, 1953 \\
\hline Cibicides pseudoungerians & Beckmann, 1953 \\
\hline Cibicides trincherasensis & Beckmann, 1953 \\
\hline Cibicides trinitatensis & Beckmann, 1953 \\
\hline Dentalina cf. cocoaensis & Cushman, 1953 \\
\hline Dentalina cf. halkyardi & Beckmann, 1953 \\
\hline Dentalina cf. inepta & Beckmann, 1953 \\
\hline Dentalina jacksonensis & Cushman, 1953 \\
\hline Dentalina mucronata & Beckmann. 1953 \\
\hline Dentalina soluta & Cushman and Kenz, 1948 \\
\hline Dentalina cf. vertibralis & Beckmann, 1953 \\
\hline Discorbis ciperense & Cushman and Stainforth, 1945 \\
\hline Dorothia biformis & Beckman, 1953 \\
\hline Ellipsonodosaria multicosta & Cushman and Renz, 1946 \\
\hline Entosolena longispina & Cushman and Stainforth, 1945 \\
\hline Entosolenia orbignyana & Cushman and Stainforth, 1945 \\
\hline Eponides umbonatus & Beckmann, 1953 \\
\hline Globocassidulina subglobosa & \\
\hline (Cassidulina subglobosa & Beckmann, 1953 \\
\hline Gyroidina jarvisi & Cushman and Renz, 1948 \\
\hline Gyroidinoides altiformis & Beckmann, 1953 \\
\hline
\end{tabular}


Gyroidinoides girardana Gyroidinoides planulata Karreriella alticamera Karreriella subcylindrica Lagena laevigata

Lagena lagenoides Laticrinina bullbroki Martinottinella prytoda Nodogenerina rohri Nodosarella subnodosa Nodosaria longiscata Nonion havanenses Nonion pompiliodes Nuttallides truempyi Oridorsalis umbonatus Orthomorphina havanensis Orthomorphina havanensis Osangularia interrupta Osangularia mexicana Planulina renzi Plectofrondicularia Pleurostomella acuta Pleurostomella alazanensis Pleurostomella alternans Pleurostomellabellardi Pleurostomella bierigi Pleurostomella nuttalli Pleurostomella subcylindrica Pseudopolymorphina ovalis Pullenia bulloides

Pullenia quinqueloba
Beckmann, 1953

Beckmann, 1953

Cushman and Stainforth, 1945

Beckmann, 1953

Beckmann, 1953

Beckmann, 1953

Beckmann, 1953

Cushman and Stainforth, 1945

Cushman and Renz, 1948

Beckmann, 1953

Beckmann, 1953

Beckmann, 1953

Cushman and Stainforth, 1945

Beckmann, 1953

Streeter (personal communication.)

Beckmann, 1953

Beckmann, 1953

Beckmann, 1953

Beckmann, 1953

Beckmann, 1953

Beckmann, 1953

Beckmann, 1953

Beckmann, 1953

Beckmann, 1953

Beckmann, 1953

Beckmann, 1953

Beckmann, 1953

Beckmann, 1953

Beckmann, 1953

Beckmann, 1953

Beckmann, 1953
Pullenia riveroi

Pulvinulinella mexicana Pyrulina extensa

Robulus cf. alato limbatus Robulus oblonga

(Cristellaria oblonga)

Robulus occidentalis grp.

Robulus plummerae

Saracenaria cf. schenki

Shenckiella petrosa

Sigmomorphina cf. trinitatensis

Sphaeroidina bulloides

Stilostomella abyssorum

Stilostomella annulifera

Stilostomella caribea

Stilostomella consobrina

Stilostomella curvatura

Stilostomella decurta

Stilostomella gracillima

Stilostomella modesta

Stilostomella nuttalli

Stilostomella seriata

Stilostomella subspinosa

Stilostomella verneuli

Uvigerina cf. auberiana Uvigerina gallowayi

Uvigerina cf. pygmaea

Uvigerina spinicostata

Uvigerina spinulosa

Bulbulina jarvisi

Vulvulina spinosa
Beckmann, 1953

Cushman and Stainforth, 1945

Beckmann, 1953

Cushman and Stainforth, 1945

Beckmann, 1953

Cushmann and Renz, 1948

Cushman and Stainforth, 1945

Cushman and Stainforth, 1945

Beckmann, 1953

Beckmann, 1953

Beckmann, 1953

Beckmann, 1953

Beckmann, 1953

Beckmann, 1953

Beckmann, 1953

Beckamnn, 1953

Beckmann, 1953

Beckmann, 1953

Beckmann, 1953

Beckmann, 1953

Beckmann, 1953

Beckmann, 1953

Beckmann, 1953

Boersma (in preparation)

Cushman and Stainforth, 1945

Boersma (in preparation)

Beckmann. 1953

Beckmann, 1953

Beckmann, 1953

Beckmann, 1953 


\section{PLATE 1}

All figures approximately $\times 40$.

Figure $1 \quad$ Nummulites sp., Site 357, Core 25.

Figure $2 \quad$ Lepidocyclina sp., Site 357, Core 25.

Figure 3 Sphaeogypsina sp., Site 357, Core 25.

Figure $4 \quad$ Truncorotaloides cf. peudotopliensis, Site 357, Core 25.

Figure $5 \quad$ Fabiania sp., Site 357, Core 25.

Figure $6 \quad$ Psedophragmina sp., Site 357, Core 25.

\section{PLATE 2}

Figure 1 Bulimina jarvisi, Site $357,23, \mathrm{CC} \times 252$.

Figure 2 Uvigerina rippensis, Site 357, 23, CC, $\times 314$.

Figure 3 Uvigerina sp., Site 357, 20, CC, $\times 297$.

Figure 4 Bulimina jarvisi, Site 357, Core 20, Section 1, $\times 197$.

Figure $5 \quad$ Uvigerina rippensis, spiny form, Site 357, Core 20, Section 1, ×188.

Figure 6 Uvigerina rippensis, low costate form, Site 357, Core 21 , Section $1, \times 142$.

Figure 7 Stilostomella aybssorum, Site 357, Core 19, Section $1, \times 95$.

Figure $8 \quad$ Uvigerina spinulosa, Site $357,18, \mathrm{CC}, \times 145$.

Figure 9 Uvigerina spinulosa, spiny morphotype during temperature minimum; Site 357, Core 18, Section $1, \times 206$.

Figure 10 Stilostomella abyssorum, spiny morphotype during the temperature minimum; Site 357 , Core 18 , Section $1, \times 56$. 


\section{PLATE 1}

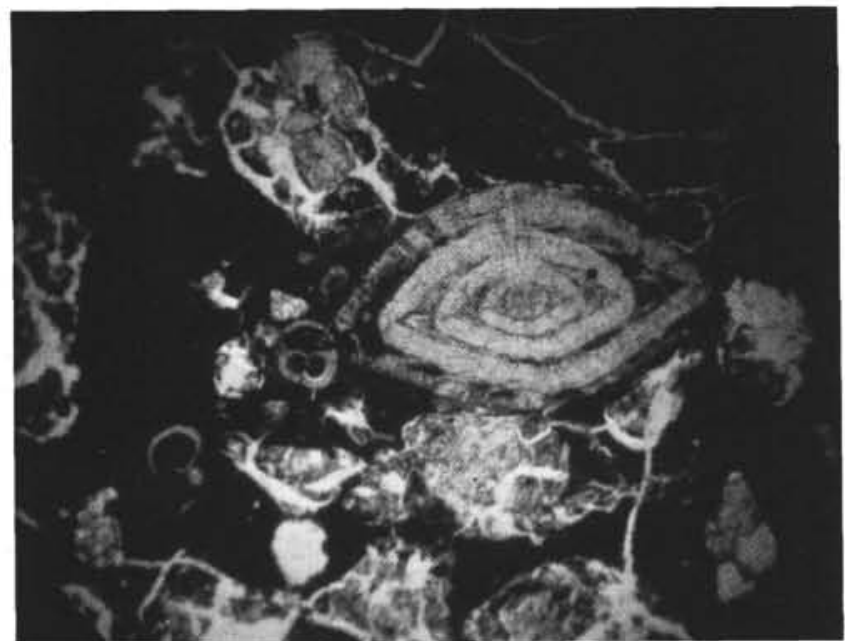

1

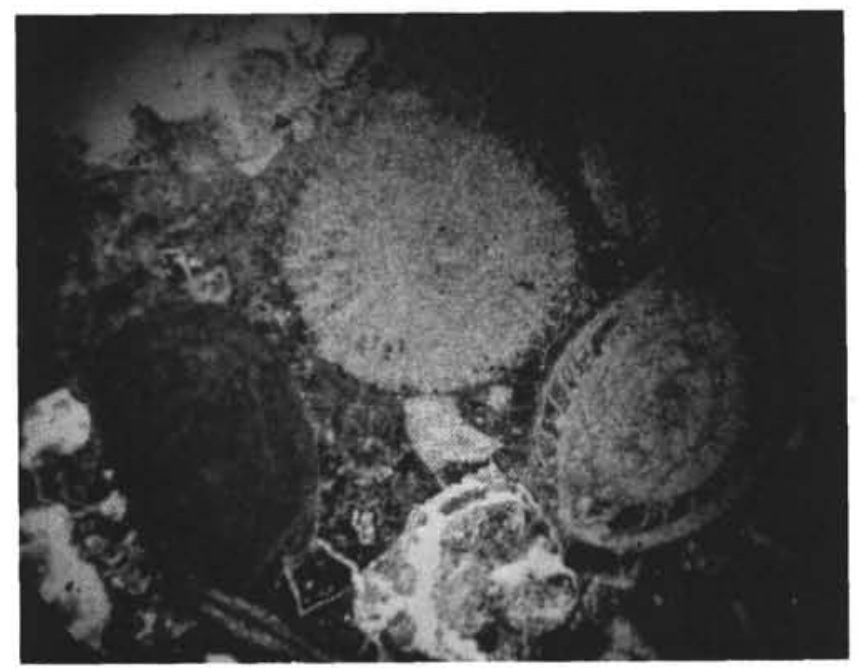

3

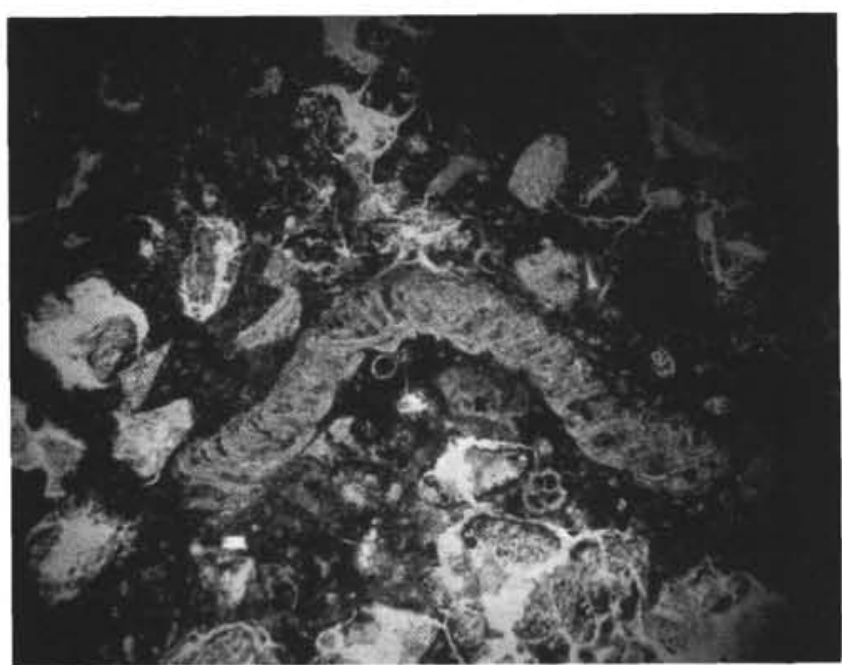

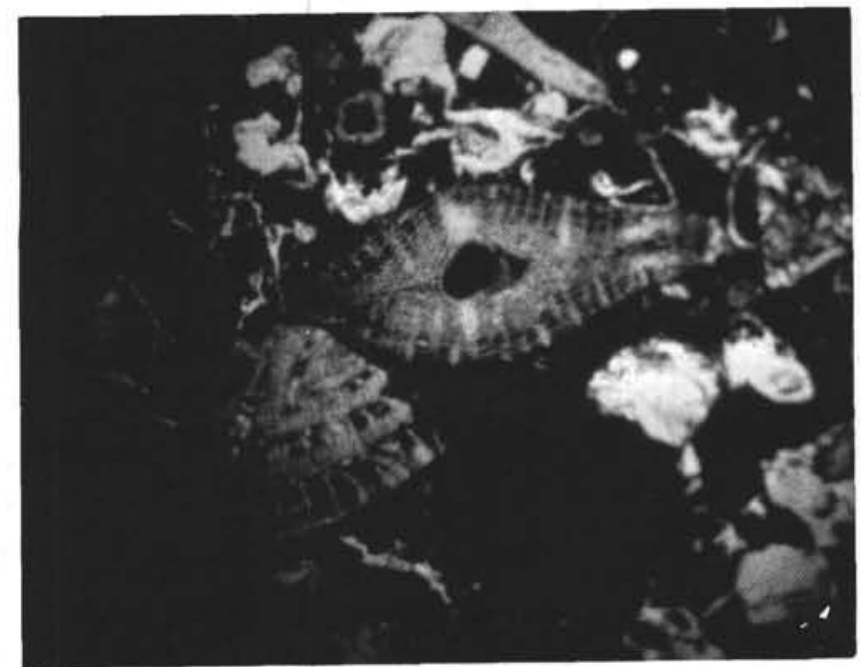

2
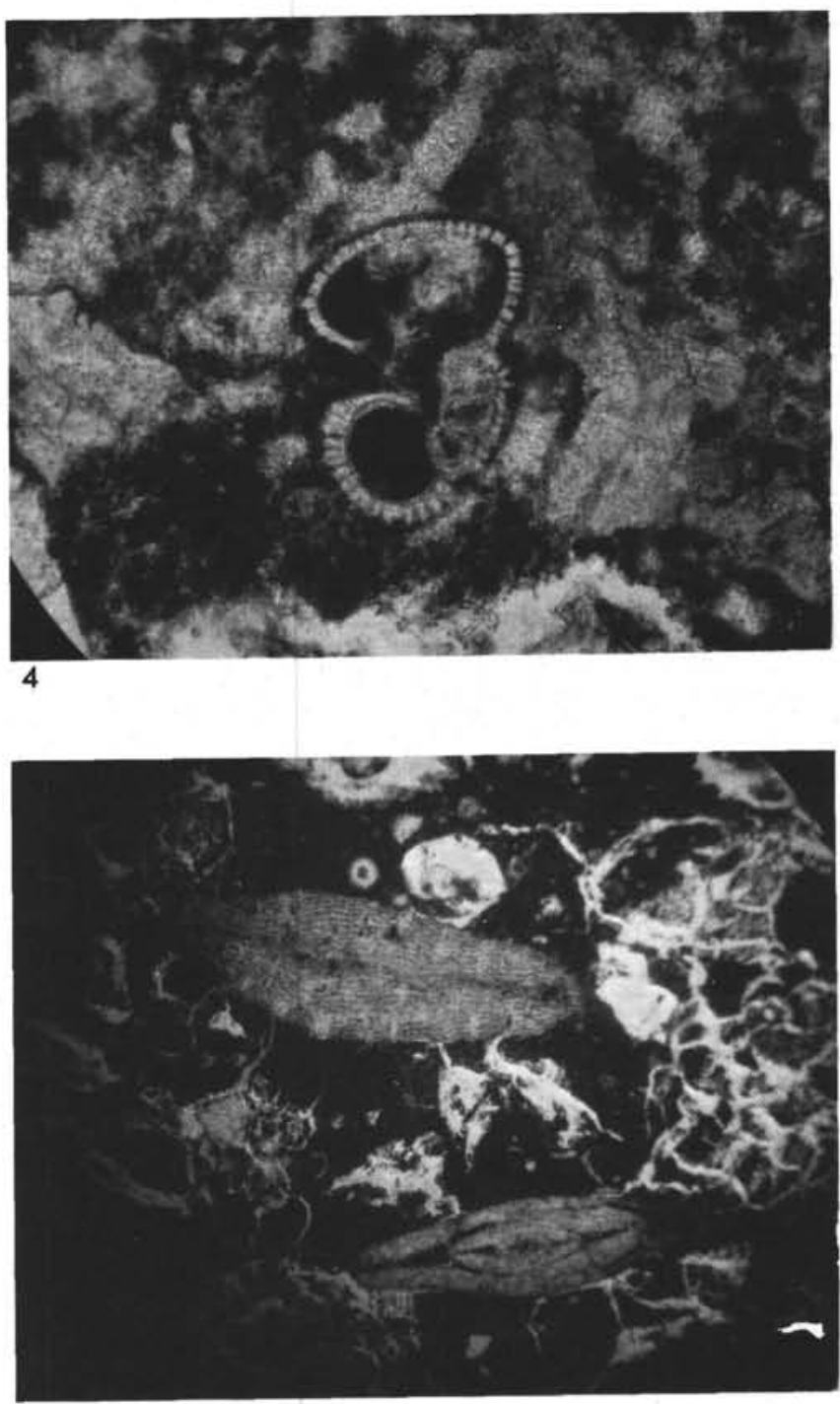

6 


\section{A. BOERSMA}

PLATE 2
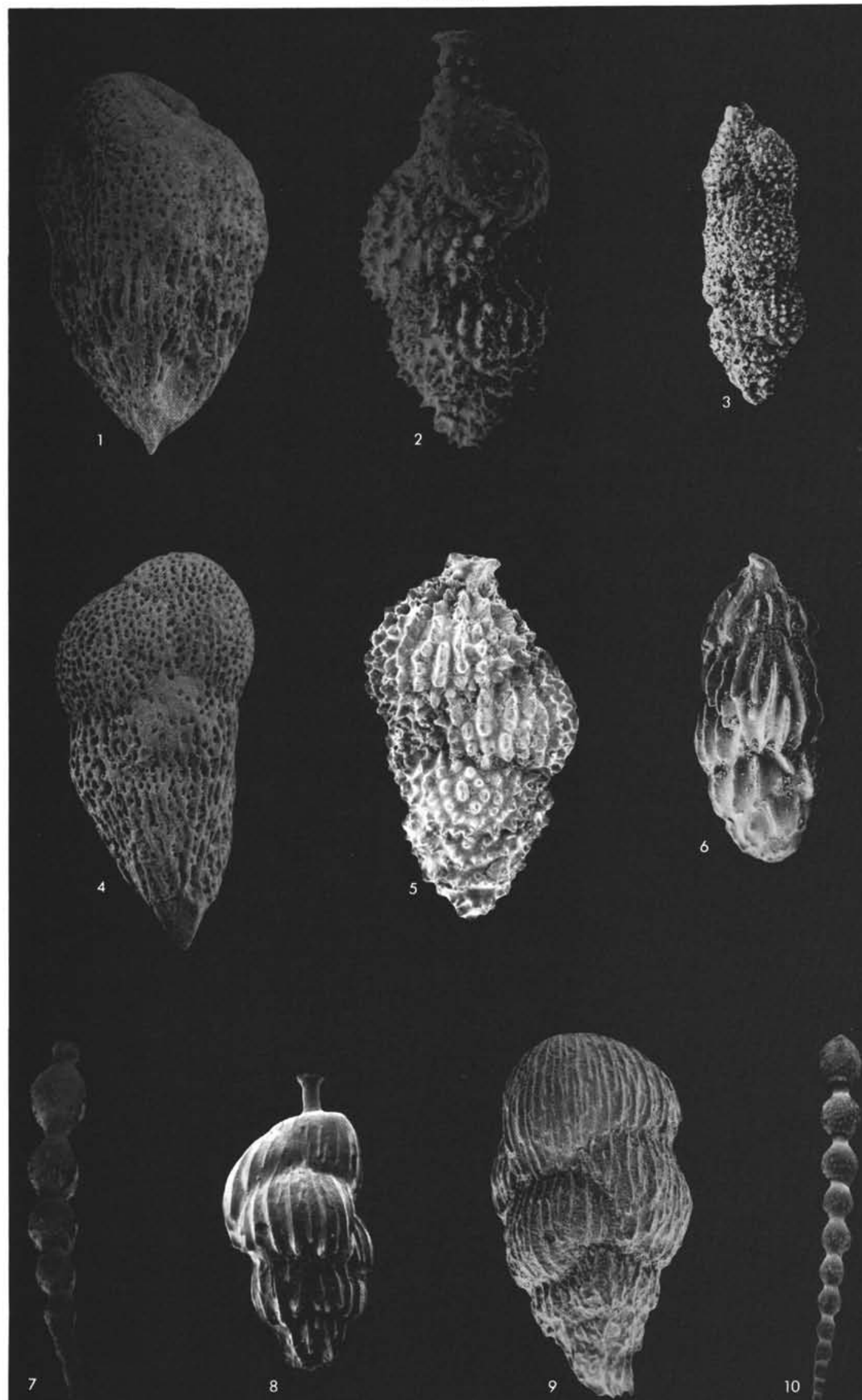


\section{PLATE 3}

Figure 1 Oridorsalis umbonatus, Site 357, 20, CC, $\times 289$.

Figure 2 Oridorsalis umbonatus, side view, Site 357, 20, CC, $\times 480$.

Figure $3 \quad$ Pullenia bulloides, Site 357, Core 20, Section 1, $\times 278$.

Figure 4 Globocassidulina subglobosa, Site 357, Core 20, Section $1, \times 287$.

Figure 5 Osangularia mexicana, Site $357,18, \mathrm{CC}, \times 189$.

Figure 6 Pullenia quinqueloba, Site 357, Core 18, Section 3, $\times 185$.

Figures 7-9 Anomalina dorri var. aragonensis, Site 357, Core 18, Section 3,

7. $\times 215$.

8. $\times 232$.

9. $\times 228$.

(see page 656) 


\section{PLATE 3}
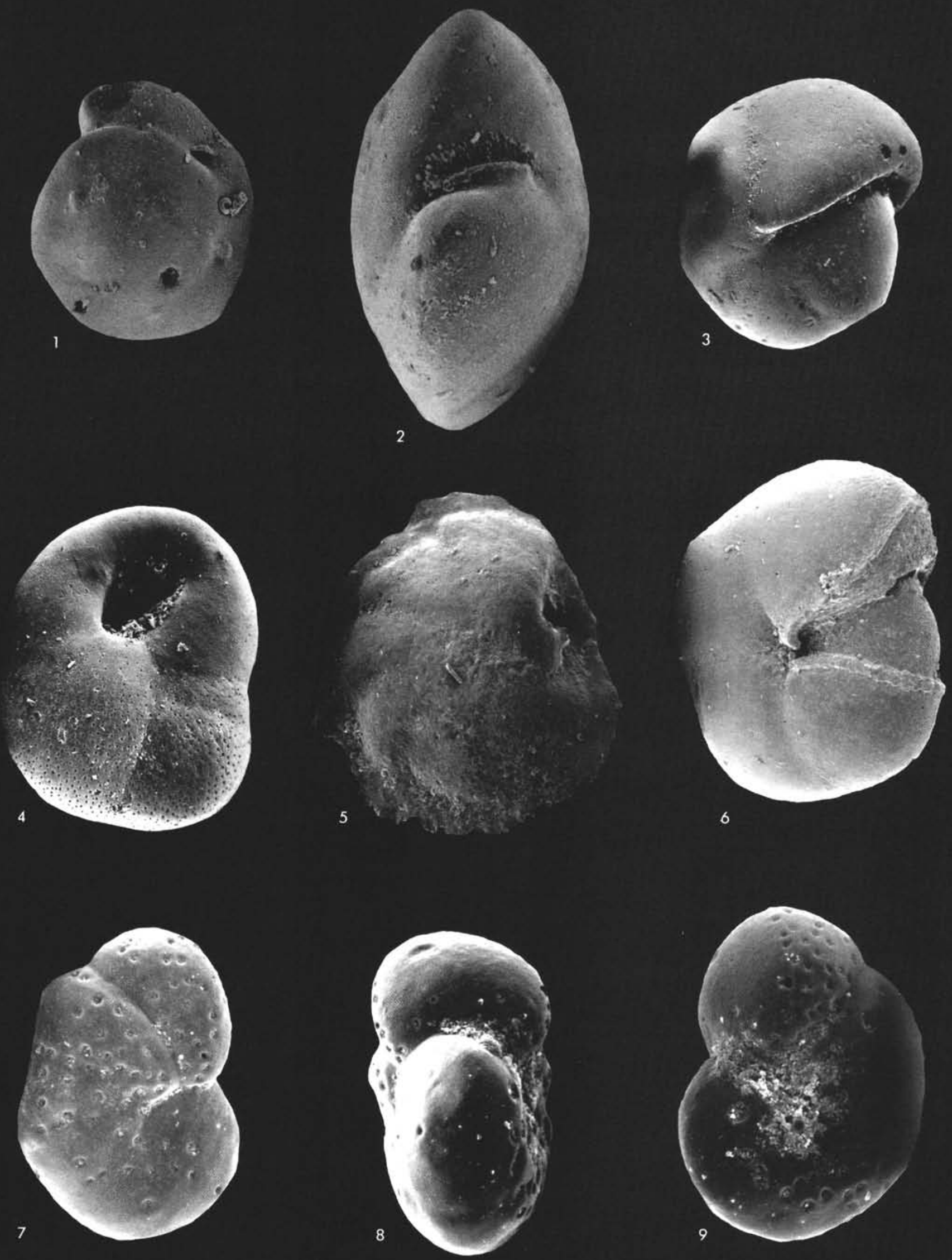